\title{
BOARD GENDER DIVERSITY, SOCIAL PERFORMANCE, AND CEO COMPENSATION
}

\author{
K. Matthew Gilley, Ph.D. \\ St. Mary's University • San Antonio, TX \\ Kelly Pledger Weeks, Ph.D. \\ Rhodes College • Memphis, TN \\ Joseph E. Coombs, Ph.D. \\ Virginia Commonwealth University • Richmond, VA \\ Myrtle P. Bell, Ph.D. \\ University of Texas at Arlington • Arlington, TX \\ Donald H. Kluemper, Ph.D. \\ University of Illinois at Chicago $\bullet$ Chicago, IL
}

\section{ABSTRACT}

This study examines the extent to which board gender diversity and corporate social performance influence CEO compensation. The sample includes 1,829 observations from 262 Fortune 500 companies over multiple years. Findings indicate that board gender diversity and corporate social performance interact to predict CEO compensation. The data show that boards comprised of a higher percentage of women place increasing emphasis on certain kinds of corporate social performance when setting CEO pay, and decreasing emphasis on other types of social performance. Our findings highlight the complex interrelationships between executive compensation, board composition, and corporate social performance.

Keywords: executive compensation, boards of directors, corporate social responsibility, diversity

\section{INTRODUCTION}

According to Main and colleagues (1995: 299), corporate governance scholars suggest that there are four key duties of a company's board of directors. They include:

"(i) overseeing of management to include the selection, monitoring, evaluation, compensation and replacement of the CEO, (ii) the management of the board to include the selection and replacement of board members, (iii) reviewing the firm's financial performance and approving the allocation of funds, and (iv) insuring compliance with the law and corporate social responsibility (e.g., Lorsch, 1989; Walsh and Seward, 1990; Jacobs, 1991)." 
There is debate, however, about whether certain characteristics of a board can detract from the board's ability to perform these tasks to the satisfaction of shareholders (Zahra \& Pearce, 1989). Anecdotal evidence suggests that maledominated boardrooms oftentimes have a "clubby" atmosphere in which executives' rewards spiral upward without legitimate reason (e.g., Burke, 1993; Ezzamel \& Watson, 2002). Ineffective board governance mechanisms provide CEOs with opportunities to implement self-interested strategic initiatives that increase their job security and compensation at the expense of long-term organizational effectiveness.

Diversifying the board may have a significant effect on board decisions (e.g., Hambrick \& Mason, 1984; Pfeffer, 1972; Post \& Byron, 2015). As such, larger boards, the presence of outsiders, and the inclusion of members of different groups (e.g. women) are presumed to be more conducive to debate and discussion of the firm's mission, strategies, and performance. Such debates may force management to consider a wider range of options, and they may clarify constraints within which strategy implementation should proceed. Over the past two decades, scholars have focused on whether more diverse boards affect firm performance, and the results have been mixed (e.g., Campbell \& Minguez-Vera, 2010; Nguyen \& Faff, 2012; Shrader, Blackburn \& Isles, 1997). Scholars have recently called for more research to assess the effect of board diversity on outcomes other than financial performance (Johnson, Schnatterly, \& Hill, 2013), and it is our assertion that one reason for the mixed results is that diverse boards may focus on different areas of firm performance (such as social performance) than homogenous boards. In addition, one area in which the board of directors uses its resources to exert influence is on executive compensation, and the question of whether women on corporate boards are influential in determining CEO compensation is important. Therefore, this study fills two gaps in the literature on diversity of corporate boards. For one, we will examine the effects of board composition on CEO pay, focusing specifically on board gender diversity. In addition, we will examine the effects of board gender diversity on the relationship between firm performance and CEO pay; however, our primary firm performance measure is social performance instead of the more traditional financial performance orientation. Our work adds to the body of knowledge on CEO compensation, corporate governance, and organizational performance. We begin by discussing executive compensation and the need for more governance. Then we will examine the statistics and literature about gender diversity on boards. Finally, we will apply upper echelon theory to explain why more gender diverse boards may take a stakeholder view of firm governance as opposed to a purely agency-related view. 


\section{EXECUTIVE COMPENSATION}

Corporate boards have been criticized for allowing excessive compensation for CEOs. One explanation about why CEO pay continues to grow is that CEOs have power in the selection of board members, and they often select other CEOs to serve who are more amenable to the idea of escalation of compensation (Burke, 1993). Debate continues in both academic literature and the popular press about the most effective ways to control CEO behavior (Devers et al., 2007; O'Connor et al., 2006). Many argue that CEO compensation is still exorbitant, compared to what most people consider fair, and it is not connected to firm performance (e.g., Delacroix \& Sandagaran, 1991). Board members are often influenced by managerial power (McConvill, 2016), cronyism, and interlocking boards (Bilimoria, 1997; Oxelheim \& Clarkson, 2015). Attempts to control increasing CEO compensation that is not clearly associated with increasing firm performance have not been successful (Bilimoria, 1997; Ogden \& Watson, 2008). Bilimoria (1997) examined the mechanisms that boards use to control executive rewards and determined that each mechanism contributed to excessive compensation, but in differing ways. Even though researchers have long argued for more outside directors on boards (e.g., Bilimoria, 1997) as a means to control escalation of pay, and there have been calls specifically for more women on corporate boards (e.g., Burke, 1993), there still is not a gender balance at the board level that reflects the larger society, which may be partly responsible for growing extremes in executive wages.

\section{GENDER DIVERSITY IN BOARDS OF DIRECTORS}

In the more than 50 years since passage of Title VII of the Civil Rights Act prohibiting sex discrimination in employment, women's presence in U.S. corporations has significantly increased. Women now comprise about half of the U.S. workforce, including increasing representation in high wage, high status, and influential positions. Although women comprise just four percent of $S \& P 500 \mathrm{CEO}$, women's representation on $S \& P 500$ boards is considerably higher, reaching over $19 \%$ in 2014, up from approximately eight percent in 1993 (Catalyst, 2014). In comparison to jobs that most women hold, women on corporate boards occupy some of the most powerful positions, with the opportunity to influence organizational decision making. Despite these recent advances, women directors remain poorly represented. Most boards have nine to 12 members (Konrad et al., 2008), but usually only one or two women. As of 2015 , nearly $5 \%$ of Fortune 500 companies still had no women on the board, while nearly $30 \%$ listed one woman director (Fairchild, 
2015). Women board members are also underrepresented in Australia, Canada, Hong Kong, India, Japan, and across Europe (Adams \& Ferreira, 2009; Catalyst, 2014), although pressures are continuing to grow in some countries for more women on their boards (Sheridan, Ross-Smith, \& Lord, 2014). In fact, the European Commission is proposing legislation that aims to have $40 \%$ of non-executive directors be women at public companies.

Women directors, often viewed as "outsiders", take their responsibility as board members seriously, consider the company's wide range of stakeholders (McInerney-Lacombe et al., 2009), and monitor and evaluate differently than men (Adams \& Ferreira, 2009). Hillman and colleagues (2000) categorized boards as having insiders, business experts, community influentials, and support specialists, each providing different resources to enhance board effectiveness. Hillman et al. (2002) showed that women and minorities serving on Fortune 1000 company boards have higher education levels and tend to be from non-business careers (support specialists and community influentials) more than the white, male board members, demonstrating that they likely provide novel resources to the board.

A growing literature indicates that women influence multiple aspects of board behavior and decision-making. McInerney-Lacombe and colleagues (2009) argue that by taking on tough issues, women directors help boards make better decisions. Evidence indicates that gender diversity on the board is related to more effective governance (Buse, Bernstein, \& Bilimoria, 2016), has a positive relationship with employee productivity (Ali, Ng, \& Kulik, 2014), and improves financial performance (Hoobler et al., 2016; Post \& Byron, 2015). Other effects of women board members include changes in leadership styles and decision making in organizations (McInerney-Lacombe et al., 2009), increased diversity of opinions, and a greater range of intellectual capital (Daily, Certo, \& Dalton, 1999), all of which may lead to more effective governance practices (Buse et al., 2016). It is still not clear, however, whether strategic changes described above are also accompanied by changes in $\mathrm{CEO}$ compensation or whether gender diverse boards reward CEOs differently than do more homogenous boards.

\section{Theoretical Explanations}

To explain why gender diverse boards may approach CEO compensation differently than homogenous boards, we will examine common theories of board governance. Specifically, we argue that upper echelon theory will explain why more gender diverse boards may take a stakeholder view of firm governance as opposed 
to a purely agency-related view.

When studying corporate boards, scholars often debate the virtues of agency theory versus stakeholder theory. Agency theory (see Jensen \& Meckling, 1976) suggests an inherent conflict between the interests of the shareholders (maximize profits) and the interests of the management (maximize their own rewards). It is assumed that top managers will choose to maximize their own interests at the expense of the company's interests. These are known as agency costs. One role of the board of directors, then, is to mitigate this conflict. They do this through incentive compensation and governance structures. However, boards often fail at this key task.

According to stakeholder theory, there are multiple stakeholders that either make contributions to the firm (normative) or constrain the corporation (derivative), and all stakeholders should be considered in board decisions (Freeman, 1984). Within stakeholder theory, there is a differentiation between a corporate egoist model and a moral stakeholder model (Jones, Felps, W. \& Bigley, 2007). The corporate egoist model considers the interests of those stakeholders who will help the firm achieve its profit goals, whereas the moral stakeholder model assumes the necessity of considering all stakeholders because it is the right thing to do. The former view can be integrated with agency theory and continues to be focused mainly on economic prosperity. The latter perspective has a more ethical nature and is often argued to be at odds with agency theory (Shankman, 1999). Therefore, the debate continues between the focus on self-interested economic profit and other-focused ethical consideration (Jones et al., 2007). If the board is focused on all stakeholders simultaneously, they may reward CEOs through higher compensation for what is typically considered social performance of the company (such as helping the environment or the community), rather than the more traditional financial performance alone.

More recently, upper echelon theory has emerged as another compelling explanation as to how women may change the monitoring behavior of boards. Most research on upper echelons theory to date has focused on how the individual characteristics of top level managers in a corporation will make a difference in the daily decisions that are made in that organization (Hambrick \& Mason, 1984). Specifically, individuals have different values, experiences, and "cognitive frames" about each decision in which they participate. Therefore, more diverse top management teams should receive the benefit of varying perspectives (Hambrick \& Mason, 1984). Research has accepted that upper echelon theory can apply to groups that "occupy formally defined positions of authority" in an organization (Pettigrew, 1992, p. 162), including corporate boards. In this manner, diverse cognitive frames can enhance information seeking and information processing behaviors on the 
board (Hambrick, 2007). Accordingly, female and male directors may influence the strategic choices of the board differently because of their different cognitive frames (Post \& Byron, 2015).

Specifically, because women directors tend to have more education, be from less traditional functional backgrounds, and are more likely to value cooperative decision making styles, and they are most often considered the "external" board member, they may have significant influence on critical board decisions (Post \& Byron, 2015). In fact, Post and Byron (2015) found that more gender-diverse boards were more engaged in strategic decisions and with CEO monitoring, especially in certain contexts (i.e., countries with higher shareholder protections). Our contention is that the higher levels of board monitoring that result from increasing gender diversity will also influence the level of CEO compensation and those factors that are used by boards to determine it. The presence of a minority in a group (in this case women) can prompt divergent thinking (van Knippenberg, De Dreu, \& Homan, 2004), not only about the primary topic of conversation, but also on related topics (Crano \& Chen, 1998) by offering unique perspectives that change the assumptions that have implicitly guided the group's reasoning (Nameth, 1986). Demographically diverse groups have been described as being more innovative, having a wider range of perspectives, and having greater task-relevant knowledge (Pelled, Eisenhardt, \& Xin, 1999; Watson, Kumar, \& Michaelson, 1993). Diverse groups may, however, have greater conflict (Pelled et al., 1999), which may influence various group outcomes, including productivity (Gladstein, 1984), performance (Pelled et al., 1999), group decision quality (Pearson, Ensley, \& Amason, 2002), and strategic decision making (Amason \& Mooney, 1999). Therefore, through infusion of different ideas and skills, the introduction of conflict into decision-making processes, and championing tough issues, upper echelon theory would indicate that women can stimulate boards to consider a wider range of problems and potential solutions, including decisions regarding $\mathrm{CEO}$ compensation, and they may move the board from an agency to model toward a stakeholder model of governance (e.g., Post \& Byron, 2015).

Strategic changes such as more corporate philanthropy (Williams, 2003), lower levels of risk taking (Hutchinson, Mack, \& Plastow, 2015), and more corporate social responsibility (Harjoto, Laksmana, \& Lee, 2015) have also been shown to be influenced by board gender diversity. Gender diversity is also positively related to more diversity policies and inclusive behaviors by board members (Buse et al., 2016). Research demonstrates that women are more likely than men to focus stakeholder concerns in several ways. For example, women on boards have greater concern for others and for interpersonal relationships (Andrews, 1992). Women directors 
are also more likely to be concerned with recruitment, retention, development, and advancement of women (Konrad et al., 2008). Women directors also support more philanthropic causes than their male counterparts (Williams, 2003). Further, women directors are more likely to contribute to corporate social responsibility (CSR) tasks as compared to operational, financial, and behavioral control tasks (Huse, 2009), and diversity in gender, tenure, and expertise on boards may lead to more CSR activities (Harjoto et al., 2015). Because of their divergent focus and past experiences, women are likely to also base their decisions about CEO compensation upon social and community factors (Ellwood \& Carcia-Lacalle, 2015), and they will likely attempt to influence the boards to consider these criteria when setting CEO pay.

In sum, agency theory promotes primarily financial motives for CEO and board decisions, and, therefore, boards use CEO pay to bring the financial interests of principals and agents into alignment. This is likely the case in less gender diverse boards. Upper echelon theory, on the other hand, suggests that board gender diversity will lead to a more robust discussion around executive compensation, resulting in a CEO's rewards being more closely linked to the outcomes of multiple stakeholders.

We argue that adding gender diversity to the board of directors may move the board's compensation focus from an agency model toward a stakeholder model because of the differing cognitive frames that women on the board contribute. Their often-nontraditional background and unique perspectives they bring to the board should drive significantly different approaches to executive compensation, especially with regard to rewarding social responsibility performance. A stakeholder-focused board would, research suggests, tie CEO compensation to the needs of a variety of stakeholders, resulting in increasing compensation for CEOs who lead their organizations to higher levels of social performance. In other words, we anticipate an interaction effect between board gender diversity and corporate social performance to predict executive compensation. Specifically, we anticipate that CEOs will have higher compensation when their board is comprised of more women and the firm has higher levels of social performance, a set of relationships that has not been studied previously.

Hypothesis: Board gender diversity and corporate social performance interact to predict CEO pay, such that boards with greater percentages of women will reward CEOs more when their firms have higher levels of social performance. 


\section{METHOD}

\section{Sample and Data Collection}

Our sample is derived from the MSCI (formerly KLD) database and the Directorship organization, which includes all firms included in Standard and Poor's 500 and is considered the most comprehensive social performance database available for U.S. corporations. The MSCI/KLD database is a primary data source for stakeholder-based research (Berman et al.,1999; Coombs \& Gilley, 2005; Hillman \& Keim, 2001; Kacperczyk, 2009; Turban \& Greening, 1997; Waddock \& Graves, 1997). Consistent with its extensive use, Sharfman (1996) established the construct validity of the KLD measures while Waddock (2003) refers to the KLD measures as the "de facto" standard for research in stakeholder management.

CEO compensation data were collected from the Execucomp database. Firmlevel financial and control variables and industry control variables were collected from the Compustat database. Governance data were collected from Directorship's annual publication and from Securities and Exchange Commission (SEC) filings. Our final sample yielded an unbalanced panel data set of 1,829 observations across 262 firms for which all variables were available for at least two consecutive years. These firms represented a total of 52 two-digit SIC code industries.

Dependent variables. Our primary dependent variables represent three forms of CEO compensation: salary, bonus, and the value of stock options granted during a given year. Stock options value was calculated using the Black-Scholes options pricing model. Values for each compensation variable are reported in thousands of dollars (see Table 1). The Black-Scholes methodology is a widely used and validated measure of stock option value (e.g., Coombs \& Gilley, 2005; O'Connor et al., 2006), allowing our results to be generalizable to other executive compensation studies (Bettis et al., 2016; O’Connor et al., 2006). The average CEO in our study had a salary of $\$ 740,000$, a bonus of $\$ 986,000$, and received stock options valued at $\$ 4.73$ million.

Predictor variables. Our predictor variables are board gender diversity and corporate social performance. Board gender diversity was measured as the percentage of women on the board. These data were collected from Directorship's annual publications and from SEC filings. The boards of directors in our sample averaged $11 \%$ women board members, which is consistent with previous research (Daily et al., 1999). The average board of directors in our sample was just over 11 individuals, with a range from 0-3 women on each board. . 
We used five corporate social performance measures best reflecting a multiple stakeholder view of the organization (Agle, et al., 1999). The five measures include: community relations, diversity, employee treatment, environmental impact, and product-related performance. Community relations includes matters related to charitable contributions, support for education, volunteer programs, and so on. Diversity addresses issues related to the promotion of women and minorities, women and minority contracting, employment of the disabled, and gay and lesbian policies. With regard to employee treatment, the MSCI/KLD data cover items such as health and safety, benefits, profit sharing, union relations, and so forth. Environmental impact includes such issues as recycling, use of clean energy, pollution prevention, and related matters. Finally, product-related performance deals with quality, innovativeness, marketing integrity, and providing services/products helping the disadvantaged. These measures have been widely used and described in the literature as valid measures of corporate social performance (Agle et al., 1999; Coombs \& Gilley, 2005; Hillman \& Keim, 2001; Kacperczyk, 2009; Waddock \& Graves, 1997). Consistent with Aiken and West (1991), we mean centered our independent variables prior to creating interaction terms.

Control variables. Six control variables were used in the analyses: firm size, CEO ownership, CEO tenure, board size, return on equity, and shareholder returns. Prior research has hypothesized or reported a significant relationship between firm size and CEO compensation (Belliveau et al., 1996; Sanders, 2001). We therefore include a commonly used measure of size, the natural logarithm of sales, to control for this potential relationship. Firm size data were collected from Compustat. Research also suggests higher levels of CEO ownership may influence CEO compensation by making CEOs more risk averse (Finkelstein, 1992; Sanders, 2001). CEO ownership was measured as the percentage of common stock owned by the CEO and was collected from Execucomp. CEO tenure may also influence CEO compensation, as CEOs tend to be more risk averse as their tenure increases (Hambrick \& Finkelstein, 1995). CEO tenure was measured as the number of days a CEO has held their position at the firm, and these were also collected from Execucomp. Board size is measured as the total number of board of director members and is expected to be negatively associated with CEO compensation as larger boards are thought to be less effective and more easily influenced by the CEO (Jensen, 1993; Yermack, 1996). CEO compensation is also believed to be influenced by financial performance (Jensen \& Murphy, 1990). We include two financial performance control variables, return on equity and shareholder return, both of which are measured as percentages. Financial performance data were collected from Compustat. Industry control variables were 
also included in our study to increase confidence in our findings. Consistent with Hillman and Keim (2001), industry dummy variables were created at the two-digit SIC code level to control for the previously identified relationship between industry affiliation and stakeholder focus (Hillman and Keim, 2001; Waddock and Graves, 1997), as well as industry affiliation and CEO compensation (Coombs \& Gilley, 2005). Industry data were collected from Compustat.

\section{Endogeneity and Reverse Causality}

Kacperczyk (2009) noted that prior research testing the relationship between effective governance and corporate attention to stakeholders has been "plagued by concerns about endogeneity" (p. 267). More specifically, the central concern is reverse causality, where significant relationships between governance and corporate attention to stakeholders may result not only from governance's influence on attention to stakeholders, but also because firms' stakeholder relationships shape the firm's governance mechanisms (Kacperczyk, 2009). Hillman and Keim (2001) also highlighted their concern regarding reverse causality between stakeholder management and firm performance. Kacperczyk (2009) emphasized that, if not addressed, endogeneity resulting from reverse causality may bias regression coefficients affecting researchers' ability to properly interpret both significant and non-significant relationships. Although a one-year lag, in addition to use of unbalanced panel data provides some assurance that reverse causality is not significantly affecting our results (Benner \& Tushman, 2002), we incorporated Hillman and Keim's (2001) suggested process whereby we estimated a 1-year lagged model using return on equity and shareholder return as dependent variables and our five social performance measures as independent variables. Our results provided no evidence of a recursive relationship between social performance and CEO compensation.

\section{Estimation Methods}

Given the likelihood that our data contain both firm-specific and time-specific effects, we use a panel estimation procedure (Chamberlain, 1982) including a White (1980) heteroskedasticity-consistent variance-covariance matrix. Because industry control variables are invariant over time, fixed-effects specifications are improper to use (Greene, 1995); therefore, we use a random-effects model with the firm as the primary stratification variable. Our panel data set includes a total of 1,829 observations. To eliminate year-specific heterogeneity, we followed Bergh's (1993) suggestion and included year dummy variables in our models. 


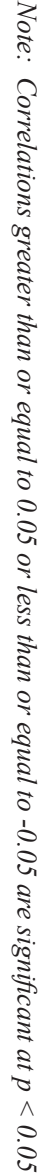

\begin{tabular}{|c|c|c|c|c|c|c|c|c|c|c|c|c|c|c|c|}
\hline$\vec{\sigma}$ & $\vec{A}$ & $\vec{\omega}$ & $\vec{N}$ & $\vec{\exists}$ & $\overrightarrow{0}$ & 0 & $\infty$ & $v$ & $\sigma$ & or & $D$ & $\omega$ & $N$ & - & \\
\hline 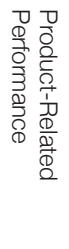 & 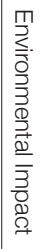 & 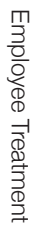 & 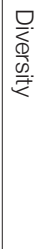 & 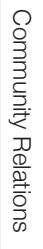 & 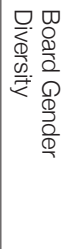 & 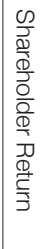 & 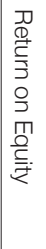 & 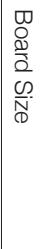 & 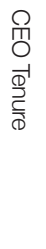 & 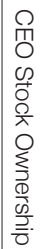 & $\begin{array}{l}\frac{1}{1} \\
\overline{3} \\
0 \\
\frac{0}{N} \\
\infty\end{array}$ & $\begin{array}{l}\frac{O}{0} \\
\frac{0}{0} \\
\frac{0}{\omega}\end{array}$ & 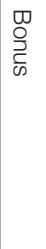 & $\begin{array}{l}\frac{\infty}{2} \\
\frac{N}{2}\end{array}$ & \\
\hline $\begin{array}{l}\dot{0} \\
\text { No }\end{array}$ & $\frac{\dot{\partial}}{\dot{\infty}}$ & $\stackrel{0}{\dot{\omega}}$ & $\stackrel{\circ}{\stackrel{\circ}{ }}$ & $\begin{array}{l}0 \\
\dot{\omega} \\
N\end{array}$ & $\stackrel{\circ}{\vec{\exists}}$ & $\begin{array}{l}\vec{\omega} \\
\omega \\
\omega\end{array}$ & $\begin{array}{l}\vec{v} \\
\overrightarrow{0}\end{array}$ & $\overrightarrow{\overrightarrow{\dot{\omega}}}$ & $\begin{array}{l}\tilde{\tilde{O}} \\
\stackrel{+}{+} \\
\text { OD }\end{array}$ & 음 & $\begin{array}{l}\infty \\
\stackrel{v}{v}\end{array}$ & 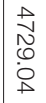 & $\begin{array}{l}0 \\
\infty \\
o \\
0 \\
0 \\
0\end{array}$ & $\begin{array}{l}\text { 屯ै } \\
\stackrel{0}{0} \\
\stackrel{1}{0}\end{array}$ & $\begin{array}{l}3 \\
\stackrel{3}{\infty} \\
\stackrel{\infty}{y}\end{array}$ \\
\hline $\begin{array}{l}0 \\
\text { o̊ } \\
\text { ơ }\end{array}$ & $\begin{array}{l}0 \\
\dot{\varphi}\end{array}$ & $\begin{array}{l}0 \\
\dot{\omega}\end{array}$ & $\vec{i}$ & ஓे & $\stackrel{\circ}{\circ}$ & $\begin{array}{l}\overrightarrow{0} \\
\dot{\omega} \\
\vec{\omega}\end{array}$ & $\begin{array}{l}\omega \\
\text { v } \\
v\end{array}$ & $\stackrel{\omega}{\vec{J}}$ & $\begin{array}{l}\text { N } \\
\text { o } \\
\text { ज) } \\
\text { cे }\end{array}$ & 웅 & $\overrightarrow{\mathrm{N}}$ & $\begin{array}{l}\vec{v} \\
\text { U } \\
0 \\
0 \\
\dot{\phi}\end{array}$ & $\begin{array}{l}\vec{v} \\
\mathbb{N} \\
\omega \\
\omega \\
v\end{array}$ & 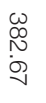 & $\begin{array}{l}\infty \\
. \\
.\end{array}$ \\
\hline
\end{tabular}

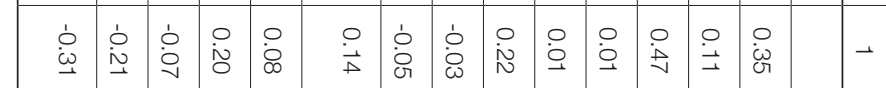

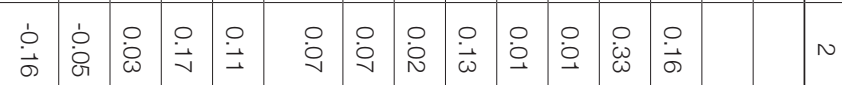

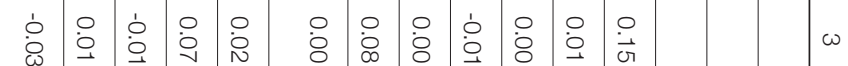

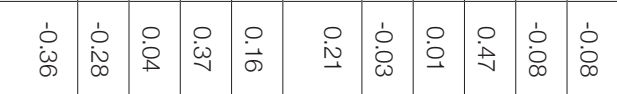

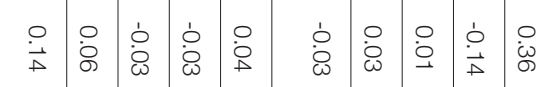

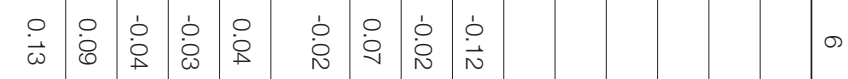

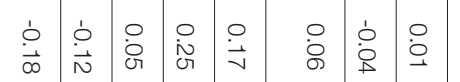

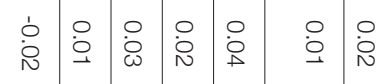

$\infty$

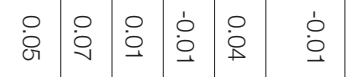

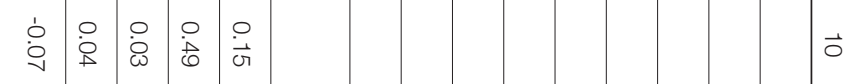

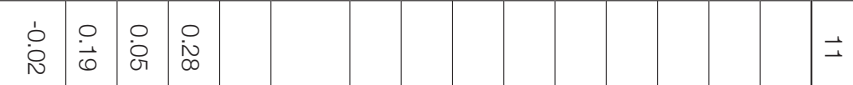

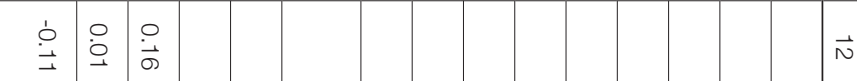

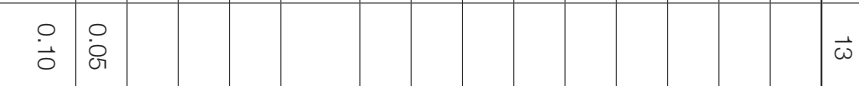


Table 2

Moderated multiple regression results for board gender diversity and social performance on CEO salary

\begin{tabular}{|c|c|c|c|}
\hline & Model 1 & Model 2 & Model 3 \\
\hline Firm Size & $101.09^{\star \star \star}$ & $100.29^{\star \star \star}$ & $104.27^{\star \star \star}$ \\
\hline CEO Ownership & -212.30 & -217.13 & -201.72 \\
\hline CEO Tenure & $-0.02^{\star \star \star}$ & $-0.02^{\star \star \star}$ & $-0.02^{\star \star \star}$ \\
\hline Board Size & -4.18 & -4.18 & -4.70 \\
\hline Return on Equity & -0.09 & -0.09 & -0.09 \\
\hline Shareholder Return & 0.09 & 0.09 & 0.10 \\
\hline Community Relations & -8.01 & -8.15 & -3.80 \\
\hline Diversity & -3.41 & -3.45 & -2.94 \\
\hline Employee Treatment & -5.79 & -5.66 & -4.27 \\
\hline Environmental Impact & $-20.65^{\star \star}$ & $-20.60^{\star \star}$ & $-20.44^{\star \star}$ \\
\hline Product-Related Performance & -13.75 & -13.56 & -8.20 \\
\hline Board Gender Diversity & & -3.94 & -149.07 \\
\hline Community x Board Gender Diversity & & & $-177.45^{\star}$ \\
\hline Diversity x Board Gender Diversity & & & $106.39^{\star \star}$ \\
\hline Employee x Board Gender Diversity & & & $-194.79^{\star *}$ \\
\hline Environment x Board Gender Diversity & & & 42.18 \\
\hline Product x Board Gender Diversity & & & $-461.88^{\star \star \star}$ \\
\hline $\mathrm{F}$ & $29.53^{\star \star \star}$ & $29.01^{\star \star \star}$ & $27.11^{\star \star \star}$ \\
\hline Partial F & & 1.09 & $2.23^{*}$ \\
\hline Adj.- R2 & 0.45 & 0.45 & 0.46 \\
\hline $\mathrm{N}$ & 1829 & 1829 & 1829 \\
\hline
\end{tabular}

Unstandardized regression coefficients

$* p<.05$

$* * p<.01$

$* * * p<.001$ 
Table 3

Moderated multiple regression results for board gender diversity and social performance on CEO bonus

\begin{tabular}{|c|c|c|c|}
\hline & Model 1 & Model 2 & Model 3 \\
\hline Firm Size & $451.85^{\star \star \star}$ & $452.91^{\star \star \star}$ & $469.88^{\star \star \star}$ \\
\hline CEO Ownership & -681.84 & -681.00 & -779.51 \\
\hline CEO Tenure & -0.00 & -0.00 & -0.00 \\
\hline Board Size & -21.43 & -21.84 & -22.03 \\
\hline Return on Equity & 0.18 & 0.18 & 0.20 \\
\hline Shareholder Return & $2.23^{\star \star \star}$ & $2.24^{\star \star \star}$ & $2.33^{\star \star \star}$ \\
\hline Community Relations & 31.58 & 31.60 & 45.48 \\
\hline Diversity & -4.74 & -1.40 & -1.16 \\
\hline Employee Treatment & $148.42^{\star \star}$ & $148.21^{*}$ & $148.06^{\star \star}$ \\
\hline Environmental Impact & $-114.28^{\star}$ & $-113.98^{*}$ & $-124.11^{\star}$ \\
\hline Product-Related Performance & -5.49 & -5.33 & -4.32 \\
\hline Board Gender Diversity & & -150.44 & -426.21 \\
\hline Community x Board Gender Diversity & & & -558.30 \\
\hline Diversity x Board Gender Diversity & & & $866.05^{\star \star}$ \\
\hline Employee x Board Gender Diversity & & & 164.27 \\
\hline Environment x Board Gender Diversity & & & $-1569.27^{\star}$ \\
\hline Product x Board Gender Diversity & & & $-1997.36^{\star \star}$ \\
\hline $\mathrm{F}$ & $11.42^{\star \star \star}$ & $11.23^{\star \star \star}$ & $11.02^{\star \star *}$ \\
\hline Partial F & & 1.04 & $4.04^{\star \star \star}$ \\
\hline Adj.- R2 & 0.23 & 0.23 & 0.24 \\
\hline $\mathrm{N}$ & 1829 & 1829 & 1829 \\
\hline
\end{tabular}

Unstandardized regression coefficients

$* p<.05$

$* * p<.01$

$* * * p<.001$ 
Table 4

Moderated multiple regression results for board gender diversity and social performance on CEO stock option value

\begin{tabular}{|c|c|c|c|}
\hline & Model 1 & Model 2 & Model 3 \\
\hline Firm Size & $2307.19^{\star \star \star}$ & $2351.52^{\star \star \star}$ & $2336.16^{\star \star \star}$ \\
\hline CEO Ownership & -6395.37 & -6494.75 & -5890.11 \\
\hline CEO Tenure & 0.02 & 0.02 & 0.07 \\
\hline Board Size & -330.26 & -353.23 & $-368.34^{*}$ \\
\hline Return on Equity & 0.29 & 0.28 & 0.39 \\
\hline Shareholder Return & $14.83^{*}$ & $15.08^{*}$ & $16.27^{\star}$ \\
\hline Community Relations & 48.12 & 45.13 & -208.66 \\
\hline Diversity & -90.90 & 81.34 & 121.36 \\
\hline Employee Treatment & -367.13 & -381.45 & -397.83 \\
\hline Environmental Impact & 450.96 & 462.22 & 351.21 \\
\hline Product-Related Performance & 324.42 & 340.47 & 497.03 \\
\hline Board Gender Diversity & & -6480.54 & -4290.76 \\
\hline Community x Board Gender Diversity & & & 7121.90 \\
\hline Diversity x Board Gender Diversity & & & 2245.13 \\
\hline Employee x Board Gender Diversity & & & $15349.79^{\star *}$ \\
\hline Environment x Board Gender Diversity & & & -3145.07 \\
\hline \multicolumn{4}{|l|}{ Product x Board Gender Diversity } \\
\hline $\mathrm{F}$ & $3.11^{\star \star \star}$ & $3.11^{\star \star *}$ & $3.25^{\star \star \star}$ \\
\hline Partial F & & 2.47 & $2.73^{\star *}$ \\
\hline Adj.- R2 & 0.06 & 0.06 & 0.07 \\
\hline $\mathrm{N}$ & 1829 & 1829 & 1829 \\
\hline
\end{tabular}

Unstandardized regression coefficients

$* p<.05$

$* * p<.01$

$* * * p<.001$ 


\section{$\overline{\text { RESULTS }}$}

Descriptive statistics and correlations are presented in Table 1. Results for our hypothesis tests using each form of CEO compensation as the dependent variable are shown in Tables 2-4. Because prior research has shown varying relationships between different types of social performance and various forms of CEO compensation (Miles \& Miles, 2013) we report results for CEO salary in Table 2, bonuses in Table 3 , and stock options in Table 4. Each of our models has variance inflation factors below 4.0, supporting the conclusion that multicollinearity is not a problem in our data set (Hair et al., 1995).

In Tables 2, 3, and 4, each Model 1 presents regression results that include the control variables and the various forms of social performance. Each Model 2 in Tables 2 through 4 adds board gender diversity, showing no main effect of board gender diversity on any of the three forms of CEO pay.

Each Model 3 in Tables 2, 3, and 4 provides results for tests of our hypothesis, namely, that board gender diversity and corporate social performance interact to predict CEO compensation. To test our hypothesis, we created interaction terms between each of the five types of social performance and the percentage of women on the board. We then tested for the influence of those interaction terms on our three forms of CEO compensation (salary, bonus, and stock options). Our results for these tests provide mixed results.

As shown in Model 3 of Table 2, community relations $\times$ board gender diversity, employee treatment $\times$ board gender diversity, product performance $\times$ board gender diversity are negatively and significantly associated with CEO salary. Diversity $\times$ board gender diversity is positively and significantly associated with CEO salary. Regarding CEO bonus (Model 3 of Table 3), environmental impact $\times$ board gender diversity and product performance $\times$ board gender diversity are negatively and significantly associated with CEO bonus, while diversity $\times$ board gender diversity has a positive and significant relationship. Lastly, employee treatment $\times$ board gender diversity is significantly and positively associated with CEO stock options while product performance $\times$ board gender diversity is significantly and negatively associated with CEO stock options.

Plotting the interactions1 sheds additional light on these relationships and provides mixed support for our hypothesis. Consistent with our hypothesis, more gender-diverse boards reward CEOs with higher salaries when diversity performance is higher. The same holds true with CEO bonuses; boards with greater representation by women reward CEOs with higher bonuses when their organization performs 
better with regard to diversity. Similarly, boards with greater representation of women reward CEOs with significantly higher stock options when their organization is more successful in terms of employee-related social performance metrics. Given that stock options represent by far the greatest percentage of a CEO's compensation package in our sample (approximately 73\%), this finding is especially important.

Contrary to our hypothesis, boards with higher percentages of women appear to compensate the CEO less in salary when community performance, employee treatment, and product-related social performance are higher. We also find lower bonuses for CEOs in companies with greater board gender diversity when both environmental impact and product-related performance are higher.

As noted, in our sample of publicly traded firms, CEO stock options were by far the largest component of executive compensation, comprising nearly threequarters of total pay. Moreover, it is clear from our analyses that women on the board exert significant influence when the board is deliberating matters related to the setting of those stock options. Specifically, when determining this most important CEO compensation component, boards comprised of more women clearly consider the extent to which the CEO is leading his/her organization to treat its employees well. In contrast, product performance indices produce lower CEO options when there is a greater percentage of women on the board. Our results indicate an important influence of women directors on the CEO compensation-setting process, particularly with broader measures of organizational effectiveness and for the single largest component of CEO pay.

\section{DISCUSSION}

The purpose of this study was to examine the extent to which CEO compensation is determined by the simultaneous influences of corporate social performance and board gender diversity. Despite being one of the most highly researched areas in the field of management, empirical investigations of CEO compensation have neglected the potential effects of board gender diversity, especially with regard to the extent to which diversity may interact with social performance. Using upper echelons theory, we argued that, because of the differing cognitive frames that women bring to the board, firms with more gender diverse boards will structure executive compensation consistent with a stakeholder model. More specifically, firms with more gender diverse boards will tie CEO compensation more closely to social performance. Our results partially support this contention, and particularly with what is by far the most important component of CEO pay, stock options. 
Generally, our results suggest that more gender-diverse boards pay CEOs more for higher performance with respect to internal forms of social performance (employees and diversity, for instance), while they pay them less when focused on external social performance measures (such as community relations, environmental impact, and product performance). Specifically, for salary and bonus, more gender diverse boards appear to place greater emphasis on the firm's diversity performance when setting the CEO's compensation. And, when determining stock options, more gender diverse boards clearly place significant weight on employee treatment by the firm.

\section{Implications for Researchers and Practitioners}

Our results provide support for van Knippenberg and colleagues' (2004) assertion that the presence of minority members can spur divergent thinking when making important decisions, as well as Harjoto and colleagues' (2015) finding that diversity on boards leads top management to consider many stakeholders in decision making. Gender diverse boards seem to be considering a wider range of inputs to the CEO pay-setting process, which is important to researchers and practitioners alike. Women on the board are offering different perspectives, changing conventional wisdom about how to reward chief executives in public companies, and challenging the board's assumptions (Nameth, 1986). Our results suggest that, to the extent that women on the board are causing the board to consider a wider range of performance metrics when setting CEO compensation, they have significant contributions to make with regard to reducing agency costs by helping the organization create shared value (Porter \& Kramer, 2011) for multiple stakeholders (Harjoto et al., 2015). Clearly, this is important to the practice of effective governance.

The necessity of inclusive HR practices and climate indicators could explain why more gender-diverse boards value employee treatment when setting stock options for CEOs. Diversity initiatives and employee treatment are clearly related. Essentially, if a company has more women on the board, the company will compensate the CEO more for paying attention to the importance of a culture that truly values diversity at all levels. When CEOs are attentive to matters of diversity, they will likely see higher employee satisfaction and morale, more innovativeness and creativity, and higher firm performance (Pelled et al., 1999).

Therefore, our results suggest that, to more fully understand the complex relationships between firm financial performance, social performance, and CEO compensation, researchers must examine board composition variables such as 
gender diversity in more detail. In addition, if researchers are to fully understand CEO compensation's antecedents and consequences, firm performance measurement in governance research needs to move beyond purely financial measures to include measures incorporating dimensions of social performance and matters of concern to other key stakeholders (see Hoobler et al., 2016). It is clear that an exclusive focus on the relationship between financial performance and CEO compensation limits our understanding of this important aspect of corporate governance.

Our results also suggest that CEOs with more diverse boards are given different signals than CEOs whose boards are more homogenous with regard to making investments in certain aspects of social performance, another important finding for practitioners. At the outset, we suspected that the interaction between various social performance measures and board gender diversity would be consistent across types of social performance and compensation categories. Our findings contradict this assumption. The findings indicate that, as boards consider inputs to CEO compensation decisions, women board members are influencing the boards to reward social investments by senior executives targeted toward key stakeholders, which include diverse employees, possibly at the expense of the broader community, the environment, and products.

\section{Limitations and Future Research}

An important limitation of our research is that it does not actually examine the complex interpersonal relationships among board members, or the specifics of how women on boards actually influence the discussions and help change the outcomes, which is a common limitation in board research (Hoobler et al., 2016). Rather, we have taken a more coarse-grained approach by using CEO compensation as a proxy for those behaviors that boards are rewarding. Researchers could extend this line of inquiry by collecting primary data from directors, especially those serving on compensation committees, dealing with the extent to which they value corporate social performance, as well as the extent to which they take measures to reward a CEO for such performance. This may shed light onto why women appear to reward "internal" social responsibility and not "external" social responsibility, which is itself an opportunity for future research. Hoobler and colleagues (2016, p. 15) called for more research measuring the "deep-level gender diversity in leadership" by assessing the power differences between men and women in organizations and how these affect communication, decisions, and even perceived position in the organization. This type of focus on specific mechanisms that drive board decisions on important 
factors such as CEO compensation would be invaluable in future research.

Another area for future research would be to specifically study how the climate for diversity and the "psychological climate of gender inequity (PCGI)" affects board decisions (Bernstein \& Billimoria, 2015; King et al., 2010). King and colleagues (2010) measured how tokenism affects several organizational outcomes, showing that tokenism experienced by women on boards can hurt their psychological ability to perform well. Hoobler and colleagues (2016) note that this is a good example of a way for future researchers to study the specific ways that women influence decisions of boards, as well as thinking about how the power differences on the board affect the women who are a part of the system. In addition, we argue that future researchers should use more mixed method studies to examine whether rewarding CEOs for firm-level diversity initiatives and employee treatment are related to the subjective experiences of employees from diverse backgrounds throughout the company.

Another limitation of our study is that the generalizability of our findings is somewhat limited. Given that our sample consisted only of the largest publicly held companies in the United States, it remains uncertain whether our results are generalizable to smaller public firms, private firms, non-profit and government agency executives, and firms outside the United States. Thus, future research might attempt to collect additional data and develop theory on the dynamic relationships among board gender diversity, social performance, and CEO compensation.

\section{CONCLUSION}

This paper has extended research into the antecedents of CEO compensation by examining the extent to which top executives' compensation is affected by board gender diversity and its interactions with corporate social performance. Our results suggest that board gender diversity plays an important role in the determination of CEO compensation, especially when measures of corporate social performance are considered. Specifically, CEOs are rewarded for considering diversity initiatives and employee treatment when the board is more gender-diverse. However, CEO pay is reduced when their board has higher levels of gender diversity and they pursue strategies focusing on more external types of social performance. Women on the board appear to generate meaningful dialog on the most appropriate ways in which to reward CEOs, resulting in boards that consider a much broader variety of performance criteria when setting CEO salaries, bonuses, and stock options.

\footnotetext{
${ }^{1}$ Interaction plots are available from the author
} 


\section{REFERENCES}

Adams, R.B. \& Ferreira, D. (2009). Women in the boardroom and their impact on governance and performance. Journal of Financial Economics, 94(2), 291-309.

Agle, B.R., Mitchell, R.K. \& Sonnenfeld, J.A. (1999). Who matters to CEO's? An investigation of stakeholder attributes and salience, corporate performance, and CEO values. Academy of Management Journal, 42(5), 507-527.

Aiken, L.S. \& West, S.G. (1991). Multiple Regression: Testing and Interpreting Interactions. Sage Publications, Newbury Park, CA.

Ali, M., Ng, Y.L., \& Kulik, C. (2014). Board age and gender diversity: a test of competing linear and curvilinear predictions. Journal of Business Ethics, 125(3), 497-512.

Amason, A.C., \& Mooney, A.C. (1999). The effects of past performance on top management team conflict in strategic decision making. International Journal of Conflict Management, 10(4), 340-359.

Andrews, P.H. (1992). Sex and gender differences in group communication: impact on the facilitation process. Small Group Research, 23(1), 74-94.

Belliveau, M.A., O'Reilly, C.A., \& Wade, J.B. (1996). Social capital at the top: effects of social similarity and status on CEO compensation. Academy of Management Journal, 39(6), 1568-1593.

Benner, M.J., \& Tushman, M. (2002). Process management and technological innovation: a longitudinal study of the photography and paint industries. Administrative Science Quarterly, 47(4), 676-706.

Bergh, D.D. (1993). Don't 'waste' your time! The effects of time series errors in management research: the case of ownership concentration and research and development spending. Journal of Management, 19(4), 897-914.

Berman, S.L., Wicks, A.C., Kotha, S., \& Jones, T.M. (1999). Does stakeholder orientation matter? The relationship between stakeholder management models and firm financial performance. Academy of Management Journal, 42(5), 488506.

Bernstein, R.S., \& Bilimoria, D. (2012). Diversity perspectives and minority nonprofit board member inclusion. Equality, Diversity and Inclusion: An International Journal, 32(7), 636-653.

Bettis, R.A., Ethiraj, S., Gambardella, A., Helfat, C., \& Mitchell, W. (2016). Creating repeatable cumulative knowledge in strategic management: a call for a broad and deep conversation among authors, referees, and editors. Strategic Management Journal, 37(2), 257-261. 
Bilimoria, D. (1997). Perspectives on corporate control: implications for CEO compensation. Human Relations, 50(7), 829-858.

Burke, R.J. (1993). Women on corporate boards of directors. Equal Opportunities International, 12(6), 5-13.

Buse, K., Bernstein, R.S., \& Bilimoria, D. (2016). The influence of board diversity, board diversity policies and practices, and board inclusion behaviors on nonprofit governance practices. Journal of Business Ethics, 133(2), 179-191.

Campbell, K., \& Minguez-Vera, A. (2010). Female board appointments and firm valuation: short and long-term effects. Journal of Management \& Governance, $14,37-59$.

Catalyst (2014). Women CEOs of the S\&P 500, Catalyst, New York [online], available at: http://www.catalyst.org/knowledge/women-sp-500-companies.

Chamberlain, G. (1982). Multivariate regression models for panel data. Journal of Econometrics, 18(1), 5-46.

Chrobot-Mason, D., \& Aramovich, N.P. (2013). The psychological benefits of creating an affirming climate for workplace diversity. Group \& Organization Management, 38(6), 659-89.

Cook, A. \& Glass, C. (2016). Do women advance equity? The effect of gender leadership composition on LGBT-friendly policies in American firms. Human Relations, 69(7), 1431-1456.

Cook, A., \& Glass, C. (2014). Women and top leadership positions: toward an institutional analysis. Gender, Work, and Organization, 21(1), 91-103.

Coombs, J.E., \& Gilley, K.M. (2005). Corporate social performance as a predictor of CEO compensation: direct effects and interactions with financial performance. Strategic Management Journal, 26(9), 827-840.

Crano, W.D., \& Chen, X. (1998). The leniency contract and persistence of majority and minority influence. Journal of Personality and Social Psychology, 74(6), 1437-1450.

Daily, C.M., Certo, S.T., \& Dalton, D.R. (1999). A decade of corporate women: some progress in the boardroom. Strategic Management Journal, 20(1), 93-99.

Day, N.E., \& Schoenrade, P. (2000). The relationship among reported disclosure of sexual orientation, anti-discrimination policies, top management support and work attitudes of gay and lesbian employees. Personnel Review, 29(3), 346-365.

Delacroix, J., \& Saudagaran, S.M. (1991). Munificent compensation as disincentives: the case of American CEOs. Human Relations, 44(7). 665-678. 
Devers, C.E., Cannella, A.A., Reilly, G.P., \& Yoder, M.E. (2007). Executive compensation: a multidisciplinary review of recent developments. Journal of Management, 33(6), 1016-1072.

Ellwood, S., \& Garcia-Lacalle, J. (2015). The influence of presence and position of women on the boards of directors: the case of NHS Foundation trusts. Journal of Business Ethics, 130(1), 69-84.

Ezzamel, M., \& Watson, R. (2002). Pay comparability across and within UK boards: an empirical analysis of the cash pay awards to CEOs and other board members. Journal of Management Studies, 39, 207-232.

Fairchild, C. (2015). The 23 Fortune 500 Companies with All-Male Boards. Fortune [online], available at: http://fortune.com/2015/01/16/fortune-500-companieswith-all-male-boards/

Finkelstein, S. (1992). Power in top management: dimensions, measurement, and validation", Academy of Management Journal, 35(3), 505-538.

Freeman, R.E. (1984). Strategic Management: A Stakeholder Approach, Pittman, Marshfield, MA.

Gladstein, D.L. (1984). Groups in context: a model of task group effectiveness. Administrative Science Quarterly, 29(4), 499-518.

Gleckman, H. (2002), The imperfect science of valuing options: there's no one way to figure how they affect earnings. BusinessWeek, 28 October 2002: 122.

Greene, W. (1995). LIMDEP Version 7.0 User's Manual, Econometric Software, Plainview, NY. Hair, J., Anderson, R., Tatham, R., \& Black, W. (1995). Multivariate Data Analysis, Prentice-Hall, Upper Saddle River, NJ.

Hambrick, D.C. (2007). Upper echelons theory: an update. The Academy of Management Review, 32(2), 334-343.

Hambrick, D.C., \& Finkelstein, S. (1995). The effects of ownership structure on conditions at the top: the case of CEO pay raises, Strategic Management Journal, 16(3), 175-193.

Hambrick, D.C., \& Mason, P.A. (1984). Upper echelons: the organization as a reflection of its top managers. The Academy of Management Review, 9(2), 193206.

Harjoto, M., Laksmana, I., \& Lee, R. (2015). Board diversity and corporate social responsibility. Journal of Business Ethics, 132(4), 641-660.

Hillman, A.J., Cannella, A.A., \& Paetzold, R.L. (2000). The resource-dependent role of corporate directors: strategic adaptation of board composition in response to environmental change. Journal of Management Studies, 37(2), 235-255. 
Hillman, A.J., \& Keim, G.D. (2001). Shareholder value, stakeholder management, and social issues: what's the bottom line? Strategic Management Journal, 22(2), 125-139.

Hoobler, J.M., Masterson, C.R., Nkomo, S.M., \& Michel, E.J. (2016). The business case for women leaders: meta-analysis, research critique, and path forward. Journal of Management [First Published , 2 March 2016], available at: doi: $10.1177 / 0149206316628643$

Huse, M. (2009). "Women directors and the 'black box' of board behavior," in Vinnicomb, S., Singh, V., Burke, R., Bilimoria, D. and Huse, M. (Eds), Women on Corporate Boards of Directors: International Research and Practice, Edward Elgar Publishing, Northampton, MA, pp.140-151.

Hutchinson, M., Mack, J., \& Plastow, K. (2015). Who selects the 'right' directors? An examination of the association between board selection, gender diversity and outcomes. Accounting and Finance, 55(4), 1071-1103.

Jacobs, M.T. (1991, cited in Main, B.G.M. et al., 1995), Short-Term America: The Causes and Cures of our Business Myopia, Harvard Business School Press, Boston, MA.

Jensen, M. (1993). The modern industrial revolution, exit, and the failure of internal control systems. Journal of Finance, 48(3), 831-880.

Jensen, M.C., \& Meckling, W.H. (1976). Theory of the firm: managerial behavior, agency costs and ownership structure. Journal of Financial Economics, 3(4), 305-360.

Jensen, M.C., \& Murphy, K.J. (1990). Performance pay and top-management incentives. Journal of Political Economy, 98(2), 225-263.

Johnson, S.G., Schnatterly, K., \& Hill, A.D. (2013). Board composition beyond independence: social capital, human capital, and demographics. Journal of Management, 39(1), 232-262.

Jones, T.M., Felps, W., \& Bigley, G.A. (2007). Ethical theory and stakeholderrelated decisions: the role of stakeholder culture. Academy of Management Review, 32(1), 137-155.

Kacperczyk, A. (2009). With greater power comes greater responsibility? Takeover protection and corporate attention to stakeholders. Strategic Management Journal, 30(3), 261-285.

King, E.B., Hebl, M.R., George, J.M., \& Matusik, S.F. (2010). Understanding tokenism: antecedents and consequences of a psychological climate of gender inequity. Journal of Management, 36(2), 482-510. 
Konrad, A.M., \& Goldberg, C.B. (2010). Asymmetrical demography effects on psychological climate for gender diversity: differential effects of leader gender and work unit gender composition among Swedish doctors. Human Relations, 63(11), 1661-1685.

Konrad, A.M., Kramer, V., \& Erkut, S. (2008). Critical mass: the impact of three or more women on corporate boards. Organizational Dynamics, 37(2), 145-164.

Lorsch, J. (1989, cited in Main, BGM et al., 1995), Pawns or Potentates: The Reality of America's Boards, Harvard Business School Press, Boston, MA.

Main, B.G., O’Reilly, C.A., \& Wade, J. (1995). The CEO, the board of directors, and executive compensation: economic and psychological perspectives. Individual and Corporate Change, 4(2), 293-332.

McConvill, J. (2006). Executive compensation and corporate governance: rising above the 'pay-for-performance' principle. American Business Law Journal, 43(2), 413-438.

McInerney-Lacombe, N., Bilimoria, D., \& Salipante, P.F. (2009). "Championing tough issues: how women corporate directors contribute to board deliberations", in Vinnicombe, S., Singh, V., Burke, R., Bilimoria, D. and Huse, M. (Eds), Women on Corporate Boards of Directors: International Research and Practice, Edward Elgar Publishing, Northampton, MA, pp. 123-139.

Miles, P.C., \& Miles, G. (2013). Corporate social responsibility and executive compensation: exploring the link. Social Responsibility Journal, 9(1), 76-90.

Nameth, C.J. (1986). Differential contributions of majority and minority influence. Psychological Review, 93(1), 23-32.

Nguyen, H., \& Faff, R. (2012). Impact of board size and board diversity on firm value: Australian evidence. Corporate Ownership and Control, 4, 24-32.

O’Connor, J.P., Priem, R.L., Coombs, J.E., \& Gilley, K.M. (2006). Do CEO stock options prevent or promote corporate accounting irregularities? Academy of Management Journal, 49(3), 483-500.

Ogden, S., \& Watson, R. (2008). Executive pay and the search for legitimacy: an investigation into how UK remuneration committees use corporate performance comparisons in long-term incentive pay decisions. Human Relations, 61(5), 711-739.

Oxelheim, L., \& Clarkson, K. (2015). Cronyism and the determinants of chairman compensation. Journal of Business Ethics, 131(1), 69-87.

Pearson, A.W., Ensley, M.D., \& Amason, A.C. (2002). An assessment and refinement of Jehn's intragroup conflict scale. International Journal of Conflict Management, 13(2), 110-126. 
Pelled, L.H., Eisenhardt, K.M., \& Xin, K.R. (1999). Exploring the black box: an analysis of work group diversity, conflict, and performance. Administrative Science Quarterly, 44(1), 1-28.

Pepper, A., Gosling, T. \& Gore, J. (2015). Fairness, envy, guilt and greed: building equity considerations into agency theory. Human Relations, 68(8), 1291-1314.

Pettigrew, A. (1992). On studying managerial elites. Strategic Management Journal, $13,163-182$.

Pfeffer, J. (1972). Size and composition of corporate boards of directors: the organization and its environment. Administrative Science Quarterly, 17(2), 218229.

Pichler, S., Ruggs, E., \& Trau, R. (2017). Worker outcomes of LGBT-supportive policies: a cross-level model. Equality, Diversity and Inclusion: An International Journal, 36(1), 17-32.

Porter, M.E., \& Kramer, M.R. (2011). Creating shared value. Harvard Business Review, 89(1/2), 62-77.

Post, C., \& Byron, K. (2015). Women on boards and firm financial performance: a meta-analysis. Academy of Management Journal, 58(5), 1546-1571.

Richard, O.C., \& Miller, C.D. (2013). "Considering diversity as a source of competitive advantage in organizations", in Roberson, Q.M. (Ed.), The Oxford Handbook of Diversity and Work, Oxford University Press, New York, NY, pp. 239-251.

Sanders, W.G. (2001). Behavioral responses of CEOs to stock ownership and stock option pay. Academy of Management Journal, 44(3), 477-492.

Shankman, N.A. (1999). Reframing the debate between agency and stakeholder theories of the firm. Journal of Business Ethics, 19(4), 319-334.

Sharfman, M. (1996). The construct validity of the Kinder, Lydenberg \& Domini social performance ratings data. Journal of Business Ethics, 15(3), 287-296.

Shrader, C., Blackburn, V., \& Iles, P. (1997). Women in management and firm financial performance: an exploratory study. Journal of Managerial Issues, 9, 355-372.

Sheridan, A., Ross-Smith, A., \& Lord, L. (2014). Institutional influences on women's representation on corporate boards: an Australian case study. Equality, Diversity, and Inclusion: An International Journal, 33(2), 140-159.

Turban, D.B., \& Greening, D.W. (1997). Corporate social performance and organizational attractiveness to prospective employees. Academy of Management Journal, 40(3), 658-672. 
van Knippenberg, D., De Dreu, C.K.W., \& Homan, A.C. (2004). Work group diversity and group performance: an integrative model and research agenda. Journal of Applied Psychology, 89(6), 1008-1022.

Waddock, S. (2003). Myths and realities of social investing. Organization \& Environment, 16(3), 369-380.

Waddock, S., \& Graves, S. (1997). The corporate social performance-financial performance link. Strategic Management Journal, 18(4), 303-319.

Walsh, J.\&, Seward, J.K. (1990, cited in Main et al., 1995). On the efficiency of internal and external corporate control mechanisms. Academy of Management Review, 15(3), 421-458.

Watson, W., Kumar, K., \& Michaelson, L. (1993). Cultural diversity's impact on interaction process and performance: comparing homogeneous and diverse task groups. Academy of Management Journal, 36(3), 590-602.

White, H. (1980). A heteroskedasticity-consistent covariance matrix estimator and a direct test for heteroskedasticy. Econometrica, 48(4), 817-838.

Williams, R.J. (2003). Women on corporate boards of directors and their influence on corporate philanthropy. Journal of Business Ethics, 42(1), 1-10.

Yermack, D. (1996). Higher market valuation for firms with a small board of directors, Journal of Financial Economics, 40(2), 185-211.

Zahra, S.A., \& Pearce, J.A. (1989). Boards of directors and corporate financial performance: a review and integrative model. Journal of Management, 15(2), 291-334.

\section{BRIEF BIOGRAPHICAL SKETCH OF AUTHORS}

K. Matthew Gilley, Ph.D., holds the Bill Greehey Chair in Ethics and Corporate Social Responsibility in the Greehey School of Business at St. Mary's University. His research has been published in Academy of Management Journal, Strategic Management Journal, Journal of International Business Studies, Journal of Management, Journal of Business Ethics, and many other outlets.

Kelly Pledger Weeks, Ph.D., is Assistant Professor of Management at Rhodes College in Memphis, Tennessee. Her research focuses on various aspects of diversity and inclusion in the workplace, including issues of race/ethnicity, LGBTQ issues, and generational differences. Her work has been published in Harvard Business Review, Journal of Applied Psychology, Journal of Business Ethics, and Equality, Diversity, and Inclusion, among others. 
Joseph E. Coombs, Ph.D., is Associate Professor of Management and Academic Director for Entrepreneurship Programs in the School of Business at Virginia Commonwealth University where he teaches courses in entrepreneurship and strategic management. His research has been published in premier academic journals including Academy of Management Journal, Entrepreneurship Theory and Practice, Journal of Business Venturing, Journal of Engineering and Technology Management, Strategic Entrepreneurship Journal, and Strategic Management Journal.

Myrtle P. Bell, Ph.D., is Professor of Management at the University of Texas at Arlington. Her research considers a wide range of diversity and social issues and appears in such outlets as Equality, Diversity and Inclusion, Human Resource Management, Journal of Organizational Behavior, and Academy of Management Journal. Her book Diversity in Organizations, a comprehensive, research-based book for teaching and learning about diversity, is in its third edition.

Don Kluemper, Ph.D., is Associate Professor of Management and Director of the Institute for Leadership Excellence and Development (iLEAD) at the University of Illinois at Chicago. Don's research has been published in outlets such as Journal of Applied Psychology, Journal of Management, Personnel Psychology, Organizational Behavior and Human Decision Processes, Journal of Organizational Behavior, and Leadership Quarterly, and his research has been featured in media outlets including the Wall Street Journal and National Public Radio. 